\title{
Malgorzata Wach-Kloskowska
}

Wyższa Szkoła Bankowa w Gdańsku

e-mail: malgorzatakloskowska@wp.pl

\section{KONKURENCJA NA RYNKU USEUG TRANSPORTU}

LOTNICZEGO WŚRÓD OPERATORÓW

PRZEWOZÓW LOTNICZYCH

\section{W RELACJACH DALEKODYSTANSOWYCH}

COMPETITION IN THE MARKET

OF AIR TRANSPORT SERVICES AMONG

AIR CARRIERS IN LONG-HAUL FLIGHTS

\section{DOI: $10.15611 / \mathrm{pn} .2018 .505 .32$}

JEL Classification: R400

Streszczenie: W niniejszym opracowaniu dokonano przeglądu literatury w zakresie specyfiki konkurencji w transporcie lotniczym, jej zasad i warunków oraz przesłanek i rodzajów. Skupiono się przede wszystkim na konkurencji wewnątrzgałęziowej ze szczególnym uwzględnieniem linii lotniczych i ich funkcjonowania na relacjach długodystansowych. Szczególnej analizie poddano alianse i porozumienia strategiczne, które są odpowiedzią na silną konkurencję ze strony przewoźników niskokosztowych. Celem opracowania jest analiza wybranych przykładów konkurencji między operatorami lotniczymi na rynku usług transportowych w relacjach dalekodystansowych. Należy uznać, że wewnątrzgałęziowa konkurencja na rynku usług lotniczych jest bardzo ostra i prowadzona jest na wielu szczeblach (poziomach). Przewoźnicy niskokosztowi widzą swoją szansę na poszerzenie rynku o przewozy w relacjach długodystansowych, z kolei przewoźnicy tradycyjni zapożyczają pewne rozwiązania od tanich linii lotniczych i proponują pasażerom hybrydowe rozwiązania.

Slowa kluczowe: transport lotniczy, konkurencja na rynku usług lotniczych, przewozy dalekodystansowe, transatlantyckie, linie lotnicze.

Summary: In this paper a review of literature on competition in air transport is presented including its terms, conditions, types and prerequisites. The article focuses mainly on intraindustry competition with particular emphasis on airlines and their operation on long-haul routes. It also analyzes alliances and strategic agreements as they have become a strong response to keen competition from low cost carriers (LCC). The aim of the study is to analyze examples of competition between air operators in long-haul routes in the transport services market. It should be underlined that the competition in the air services market is fierce and occurs on many levels. On the one hand, low cost carriers seek for opportunities to expand 
their business and enter long-haul markets and on the other, traditional carriers take advantage of some solutions from LCC and offer hybrid ones to their passengers.

Keywords: air transport, competition in the market of air transport, long-haul flights, transatlantic routes, airlines.

\section{Wstęp}

Rozwój transportu lotniczego determinowany jest ogólnymi przemianami i trendami rozwoju gospodarki światowej. Jednocześnie tempo tego rozwoju silnie oddziałuje na rozwój światowej gospodarki. Rola transportu lotniczego jako podstawy, czynnika czy siły napędzającej gospodarkę światową jest niezaprzeczalna i potwierdzona wieloma badaniami. Wiele działalności gałęzi przemysłu, działów gospodarki (np. turystyka) czy funkcjonowanie gospodarstw domowych uzależnionych jest od funkcjonowania i rozwoju transportu lotniczego. Zauważyć można ścisłą korelację pomiędzy tempem wzrostu lotniczych przewozów pasażerskich a tempem wzrostu gospodarczego głównych gospodarek świata.

\section{Prognozy rozwoju rynku transportu lotniczego}

W ostatnich dziesięcioleciach zauważa się dynamiczny wzrost liczby lotniczych przewozów pasażerskich na rynku globalnym. W 2015 r. przewozy pasażerskie kolejny już raz wzrosły w stosunku do poprzedniego roku (o 8\%). Największy udział miał region Azji i Pacyfiku, w którym obsłużono 1,1 mld pasażerów (33\% rynku światowego). Na drugim miejscu znalazła się Europa - 873,4 mln pasażerów (26,3\%), a na trzecim Ameryka Północna - 841,8 mln (25,3\%).

Perspektywy rozwoju przewozów pasażerów transportem lotniczym do $2034 \mathrm{r}$. według IATA przewidują znaczny wzrost przewozów. W roku 2034 liczba pasażerów globalnie osiągnie 7,3 mld (w roku 2015 - 3,5 mld [Tłoczyński 2015]). Oznacza to średnioroczny wzrost na poziomie $4,1 \%$.

Odnosząc się do opracowań przygotowanych przez producentów samolotów komunikacyjnych, Boeinga (Current Market Outlook) i Airbusa (Global Market Forecast), należy potwierdzić, że do czynników powodujących większy wzrost przewozów (niż wzrost PKB) zaliczyć trzeba [Airbus... 2010, s. 13]:

- Zastępowanie starych samolotów nowymi (na rynkach Europy Zachodniej, Ameryki Północnej, Japonii, Australii).

- Dynamiczny rozwój rynków wschodzących (Chiny, Indie, Bliski Wschód, Afryka, Ameryka Łacińska, wschodnia Europa).

- Kontynuacja rozwoju segmentu przewozów niskokosztowych.

- Skuteczniejsza kontynuacja liberalizacji rynku usług transportu lotniczego.

- Wzrost ruchu lotniczego na istniejących trasach, poprzez zastąpienie samolotów o mniejszej pojemności samolotami większymi (zamiast zwiększania częstotliwości połączeń). 
Szacuje się, że prognozowany wzrost wielkości przewozów wygenerowany zostanie głównie w Azji (31\% wzrostu światowych przewozów), Europie (8\%), Ameryce Północnej (8\%), na połączeniach między Europą i Azją (7\%), pomiędzy Europą a Ameryką Północną (7\%). Najwięcej przewozów odnotuje Azja (27\% ogólnoświatowych przewozów), Ameryka Północna (12\%) oraz Europa (11\%) [Current... 2011, s. 5-32; Tłoczyński 2013, s. 384].

\section{Istota konkurencji wewnątrzgałęziowej na rynku usług transportu lotniczego}

Konkurencja w odniesieniu do transportu lotniczego nie jest zjawiskiem jednorazowym, lecz procesem, który zachodzi pomiędzy sprzedawcami usług lotniczych bądź ich nabywcami. Kupujący rywalizują o usługę lotniczą, natomiast sprzedający o możliwość uzyskania wpływów z jej sprzedaży. Podmioty lotnicze rywalizują o udziały w rynkach i uzyskanie na nich przewagi konkurencyjnej. O konkurencji wewnątrzgałęziowej można mówić, gdy rywalizacja występuje pomiędzy przedsiębiorstwami zaangażowanymi w funkcjonowanie transportu lotniczego - przewoźnikami, portami lotniczymi, agentami handlingowymi oraz producentami taboru i sprzętu lotniczego. Konkurencja może występować zarówno pomiędzy przedsiębiorstwami istniejącymi już na rynku, jak i między podmiotami już funkcjonującymi na rynku a nowo powstającymi. Rywalizować można o pasażerów, ładunki, rynki zbytu usług, zaopatrzenia w surowce, środki pracy, materiały i siłę roboczą, w celu osiągnięcia jak największych korzyści ekonomicznych [Koźlak 2007, s. 244].

Na rynku transportu lotniczego przedsiębiorstwa konkurują ze sobą najczęściej poprzez cenę za świadczoną usługę, kształtując i zmieniając jej poziom, oraz poprzez element pozacenowy, który wynika z wykorzystywania i reagowania na zmiany innych instrumentów konkurencji (np. różnicowania usługi lotniczej, promocji, sposobów dystrybucji, oferty usług dodatkowych). Na rynku usług lotniczych najczęściej konkurują przewoźnicy oraz porty lotnicze. Przewoźnicy w ramach konkurencji wewnątrzgałęziowej wykorzystują wszystkie instrumenty i formy konkurencji jednocześnie. Do najczęściej wykorzystywanych przez przewoźników lotniczych instrumentów konkurowania zalicza się: ceny biletów, oferowaną siatkę połączeń (jej atrakcyjność, częstotliwość lotów, dostępność i lokalizację portów lotniczych), jakość usługi (klasę i standard podróży, odstępy między fotelami, odpowiedzialność, wrażliwość i empatię personelu), eksploatowany tabor (rodzaj samolotu, liczbę miejsc w poszczególnych klasach), markę przewoźnika (wiarygodność, profesjonalizm i kwalifikacje personelu lotniczego), usługi dodatkowe świadczone przez przedsiębiorstwa lotnicze (bezpłatny catering, pierwszeństwo wejścia na pokład samolotu, limity bagażu rejestrowanego i podręcznego), warunki nabycia biletu (np. w kasie na lotnisku, za pośrednictwem biura podróży, Internetu), dostępność usługi (strona internetowa, infolinia, biura przedstawicielskie przewoźników), kampanie promocyjne (organizowane kampanie informacyjne, promocje cenowe), współpraca z innymi operatorami lotniczymi 
i podmiotami spoza sektora lotniczego, np. przewoźnikami transportu kolejowego, autobusowego, punktami wynajmu samochodów, hotelami [Rucińska i in. 2012, s. 148].

Konkurencja w transporcie jest zjawiskiem nieodłącznie związanym z funkcjonowaniem na rynku usług. Wpływ na rozwój procesów rywalizacji w transporcie lotniczym miały liberalizacja oraz deregulacja rynku. Natomiast główną determinantą przeobrażeń funkcjonalnych oraz strukturalnych jest polityka „otwartego nieba”, która opiera się na założeniu wprowadzenia udogodnień w transporcie lotniczym na trasach transatlantyckich.

\section{Alianse i porozumienia jako forma współpracy/ konkurencji między liniami lotniczymi}

Z globalizacji, liberalizacji i deregulacji transportu lotniczego wynika konieczność nowych form koordynacji rozproszonych gałęzi rynków. Wyraża się ona tworzeniem aliansów strategicznych i porozumień lotniczych, które od początku lat 90 . XX wieku stały się głównymi elementami globalnych strategii na rynku.

Przedsiębiorstwa lotnicze coraz częściej funkcjonują poprzez koncentrację przewoźników w ramach aliansów strategicznych. Powstają one w celu nawiązania współpracy pomiędzy obecnymi bądź potencjalnymi konkurentami, którzy decydując się na podjęcie kooperacji, powinni uwzględnić obowiązek udostępnienia posiadanego know how oraz środków drugiej stronie, co w konsekwencji ma przynieść obopólne korzyści wszystkim zaangażowanym podmiotom. Współpraca poszczególnych partnerów powinna opierać się na równowadze, bez której zaistnieć mogą nie zawsze pożądane zjawiska, takie jak fuzje bądź przejęcia [Biskup 2013, s. 207]. Alians strategiczny to sojusz zawiązany między przedsiębiorstwami w celu polepszenia pozycji konkurencyjnej, który zawiera zarówno elementy współpracy, jak i konkurencji, rywalizacji. Można zatem stwierdzić, że alians jest tworem pośrednim między kooperacją a współzawodnictwem [Malara 2006, s. 41].

W dzisiejszym świecie konkurencja opiera się przede wszystkim na zaciętej walce o pasażerów pomiędzy liniami lotniczymi. Zawierane sojusze dotyczą w znacznym stopniu ekspansywnych operatorów, często skoncentrowanych w porozumieniach strategicznych, którzy oferują zróżnicowane usługi w zakresie ceny, jak i jakości.

Ponadto należy zaznaczyć, że umowy o współpracy w ramach aliansów strategicznych mogą zawierać elementy konkurencji i kooperacji, ponieważ alianse te często powstają między konkurentami; stąd takie umowy mogą być traktowane jako swoiste „zawieszenie broni” firm rywalizujących na rynku [Rucińska (red.) 2015, s. 170].

Powszechnym zjawiskiem na globalnym rynku przewozów lotniczych są połączenia poprzez przejęcia i fuzje. Sprzyjają one kapitałowemu wzmocnieniu partnerów, rozwojowi dobrej współpracy, pozyskiwaniu nowych, w tym niszowych, rynków, destynacji, wzmacnianiu oferty, utrwalaniu pozycji i marki przejmującego przewoźnika [Tłoczyński 2013, s. 394-395]. 


\section{Filozofia funkcjonowania tradycyjnych linii lotniczych i przewoźników niskokosztowych}

Model biznesowy niskokosztowych przewoźników (Low Cost Carriers - LCC) opiera się przede wszystkim na redukcji kosztów pośrednich, m.in. zarządu, sieci przedstawicielstw, oddziałów zagranicznych, sprzedaży biletów, działalności marketingowej, w tym promocji itp. Często redukcja tych kosztów sięga 50\% udziału łącznych kosztów funkcjonowania tradycyjnych, pełnokosztowych linii lotniczych. Poza tym przewoźnicy LCC redukują bezpośrednie koszty operacyjne, np. taboru, poprzez eksploatację jednego typu samolotów (Boeing 373, Airbus 320); lotniskowe, poprzez korzystanie $\mathrm{z}$ tańszych, regionalnych bądź peryferyjnie zlokalizowanych portów lotniczych; obsługi pasażerów przez likwidację cateringu pokładowego, dostępu do prasy itp.

Dzięki znaczącej redukcji stawek przewozowych niskokosztowi przewoźnicy dotarli do wielu niszowych segmentów rynku usług lotniczych. Oferując tanie usługi (ok. 10-100 EUR), wygenerowali popyt wśród nabywców, którzy nigdy wcześniej ze względów ekonomicznych nie korzystali z usług świadczonych na tym rynku. Do najbardziej aktywnych europejskich niskokosztowych przewoźników należą: irlandzki Ryanair, angielski EasyJet, węgierski WizzAir. Obsługują oni do kilkudziesięciu milionów pasażerów rocznie (Ryanair - ponad $100 \mathrm{mln}$ w 2015 r.) przy bardzo wysokim wskaźniku wykorzystania miejsc w samolocie - 73-82\% (Ryanair -91\%).

$\mathrm{Na}$ trasach europejskich tani przewoźnicy wypierają tradycyjne linie lotnicze. Liberalizacja rynku lotniczego zarówno w Europie, jak i w Ameryce, spowodowała wzrost konkurencji i spadek cen biletów na trasach transatlantyckich, na których np. PLL LOT jeszcze kilkanaście lat temu był jedynym przewoźnikiem obsługującym połączenia z Polski. Niskokosztowi przewoźnicy funkcjonują też z powodzeniem na rynku amerykańskim (np. Jet Blue, Southwest), azjatyckim i australijskim (np. AirAsia). Można zatem stwierdzić, że niskokosztowi przewoźnicy stali się ważnym elementem współczesnego, światowego rynku lotniczych przewozów pasażerskich [Wojewódzka-Król, Załoga (red.) 2016, s. 276-278].

\section{Przykłady konkurencji między operatorami lotniczymi na trasach dalekodystansowych}

Coraz częściej połączenia dalekodystansowe są przedmiotem zainteresowania tanich linii lotniczych. Trasy przez Atlantyk stanowią wyzwanie dla tanich linii, przede wszystkim dlatego, że podlegają większej konkurencji ze strony tradycyjnych linii lotniczych. Ponadto do ceny biletu na loty transatlantyckie trzeba doliczyć szereg podatków i opłat. Oznacza to, że cena podstawowa (bez podatków i opłat) jest relatywnie niska. Tradycyjni przewoźnicy równoważą swoje koszty dzięki wysokim cenom biletów w klasach premium. Na odcinku o podobnej długości między Azją 
Południowo-Wschodnią i Australią nie ma takiego problemu. Różnica w cenie między biletami w klasie turystycznej i premium jest dużo mniejsza. Bilety w najniższej klasie są droższe niż w przypadku połączeń transatlantyckich, ale podatki i opłaty stanowią mniejszą część całej ceny. Innymi słowy, przychód z jednego fotela w klasie turystycznej jest znacznie wyższy [McWhirter 2014].

Historia udowodniła, że loty trwające ponad osiem godzin to dla tanich linii mało opłacalny interes. AirAsia X, kanadyjska Zoom i hongkońska Oasis wprowadzały takie połączenia, ale wszystkie musiały z nich zrezygnować. Tanie linie zarabiają na każdym odcinku podróży, jaki obsługują. Dlatego w Europie jeden samolot takiego przewoźnika może wykonywać aż do ośmiu lotów dziennie. Jest to zatem osiem szans na osiągnięcie zysku wynikającego z niższych kosztów operacyjnych oraz wpływów z opłat dodatkowych. Jednak na trasach długodystansowych tani przewoźnik ponosi takie same koszty jak inne linie, ponieważ nie da się uniknąć opłat trasowych i paliwowych [McWhirter 2014].

Od początku lat 80 . XX wieku żadna tania linia lotnicza nie próbowała konkurować z tradycyjnymi przewoźnikami na trasie Londyn - Nowy Jork. W 2014 r. Norwegian zaproponował swoim pasażerom loty na trasie Londyn - Nowy Jork w cenie od 149 GBP. Należy jednak stwierdzić, że był to zabieg marketingowy, ponieważ w ciągu 9 miesięcy (lipiec 2014 r. - marzec 2015 r.) pasażerowie mogli zarezerwować zaledwie w cztery dni tak tanie loty [Can Norwegian... 2014].

Niedawno Norwegian ogłosił, że pasażerowie od lata 2017 r. będą latać bezpośrednio do Nowego Jorku za mniej niż 60 GBP. Jest to kolejny krok tego przewoźnika w konkurencji na rynku przewozów transatlantyckich. Norweski przewoźnik planuje podjąć wyzwanie wobec największych przewoźników, w tym British Airways, wprowadzając opłaty już od 56 GBP na nowych trasach z Edynburga w Szkocji oraz z Cork i Shannon w Irlandii. Linia twierdzi, że może zaoferować tak niskie stawki, wprowadzając na te trasy efektywne i oszczędne samoloty, zużywające mniej paliwa, oraz latając do mniejszych portów lotniczych w Nowym Jorku, gdzie opłaty lotniskowe są niższe. Obecnie Norwegian lata codziennie z Londynu Gatwick do John F. Kennedy Airport w Nowym Jorku, a ceny zaczynają się od 149 GBP. Od początku 2017 r. linia planuje zwiększyć liczbę lotów na tej trasie do dwóch razy dziennie. Norwegian uruchomił również loty długodystansowe z Gatwick do Bostonu, Los Angeles, San Francisco-Oakland-Fort Lauderdale, Orlando, Las Vegas i Puerto Rico, w jednokierunkowych cenach od 135 GBP [Monaghan 2016].

Wielu tradycyjnych przewoźników szuka swojej szansy w przejęciu części rynku długodystansowych podróży samolotem. International Airlines Group (IAG), właściciel British Airways, chce uruchomić tanie loty transatlantyckie. Grupa zapowiedziała, że rozpocznie latanie z lotniska El Prat w Barcelonie do USA w czerwcu 2017 r., pod sztandarem nowej linii lotniczej, jako część przewoźnika BA i Iberia, lub za pośrednictwem swojej niskokosztowej długodystansowej linii lotniczej Aer Lingus. Oprócz takich miejsc jak Los Angeles i San Francisco, rozważane są również tańsze trasy do Buenos Aires, Santiago, Hawany i Tokio. 
Analitycy transportu lotniczego uważają, że zapowiadane przez IAG operacje są odpowiedzią na zwiększenie liczby połączeń na długich trasach oferowanych przez szybko rozwijających się rywali, np. Norwegiana. Już od kilku lat tanie linie lotnicze próbują konkurować z tradycyjnymi liniami lotniczymi (mocnymi, stabilnymi graczami) na trasach długodystansowych, poprzez przebicie ich ceny. Uważa się, że tradycyjne linie lotnicze zbyt późno zareagowały na rozwój tanich linii lotniczych na krótkich dystansach. Obecnie, konkurując na dłuższych trasach, nie mogą popełnić tego samego błędu i nie mogą pozwolić na rozwój tanich długodystansowych tras bez własnego aktywnego udziału [BA owner... 2016].

Ugruntowane linie lotnicze, takie jak British Airways, American Airlines i Delta, są przyzwyczajone do operowania na lukratywnych trasach transatlantyckich, ale funkcjonowanie to jest coraz trudniejsze w obliczu rosnącej konkurencji ze strony nowych podmiotów niskobudżetowych, tj. Norwegiana czy Wow Air, oferujących letnie przeloty z USA do Europy w cenie 99 USD za bilet w jedną stronę (Boston lub Waszyngton - Reykjavik). To skłoniło tradycyjne linie lotnicze do rozwijania własnych niskokosztowych przedsięwzięć. Na początku 2016 r. tania linia lotnicza Eurowings, jako część Lufthansy, zaczęła latać na trasach długodystansowych z Kolonii na Kubę, do Tajlandii i Republiki Dominikany, a obecnie rozważa wprowadzenie połączeń z Monachium. Podobnie Air France rozważa otwarcie nowych tras do USA, jednak oferta nie została jeszcze skonstruowana [BA owner... 2016].

Analizując rynek przewozów dalekodystansowych, należy także zwrócić uwagę na działania Ryanaira. Okazuje się, że irlandzki przewoźnik zamierza podpisać umowę o współpracy z liniami Norwegian.com i Aer Lingus w zakresie dowozu pasażerów na loty dalekodystansowe z Dublina i Londynu-Gatwick. Będzie to pierwsza w historii współpraca Ryanaira z innym przewoźnikiem i pierwsza na świecie tego typu umowa linii niskokosztowych. Skorzystają na tym pasażerowie, m.in. z Polski, którzy będą mogli korzystać z wielu nowych możliwości lotów dalekodystansowych. Zgodnie $\mathrm{z}$ umową pasażerowie będą mogli zarezerwować lot z przesiadką w Dublinie lub Londynie-Gatwick, obejmujący podróż dalekodystansową odpowiednio Aer Lingusem i Norwegianem oraz dolot na odcinku europejskim Ryanairem [Sipiński 2017].

Jeśli dojdzie do podpisania porozumienia i obejmie ono loty z Polski, PLL LOT zyska nowego konkurenta. Polski przewoźnik lata obecnie do Toronto w Kanadzie oraz do Nowego Jorku-JFK i Chicago-O’Hare w Stanach Zjednoczonych. W kwietniu uruchomi połączenia z Warszawy do Newark i Los Angeles, a w lipcu z Krakowa do Chicago. Wszystkie północnoamerykańskie kierunki LOT-u są również obsługiwane przez Norwegiana i Aer Lingus. Ponadto linie te latają m.in. do San Francisco, Bostonu i na Florydę, a Norwegian także do Las Vegas.

Rynek lotów dalekodystansowych od lata 2017 r. powiększy się również o nowe połączenia na trasach Londyn-Gatwick - Kuala Lumpur oraz Frankfurt - Bangkok, obsługiwanych przez malezyjskiego przewoźnika AirAsia, uznawanego za najlepszą tanią linię na świecie. Ceny biletów mają rozpoczynać się od 150 EUR. Malezyjska linia latała już kilka lat temu z Malezji do Paryża i Londynu, jednak obie trasy 
z powodu niewystarczającej opłacalności zostały zawieszone w marcu $2012 \mathrm{r}$. Obecnie AirAsia X przymierza się do uruchomienia większej liczby tras z Europy do Azji, rozważając rozpoczęcie lotów z Bangkoku do Europy Środkowo-Wschodniej. Wśród potencjalnych destynacji, do których mógłby polecieć tani przewoźnik, są Warszawa, Praga i Budapeszt [Piotrowski 2017].

\section{Zakończenie}

Rynek usług lotniczych funkcjonuje w przestrzeni globalnej, a zmiany zachodzące na nim w ostatnich latach są niezwykle dynamiczne. Należy stwierdzić, że wewnątrzgałęziowa walka konkurencyjna prowadzona przez przewoźników lotniczych na trasach dalekodystansowych jest bardzo zróżnicowana i intensywna. Przewoźnicy niskokosztowi postrzegają swoją szansę na rozszerzenie rynku o przewozy w relacjach długodystansowych i prowadzą swoją działalność coraz odważniej, wdając się w walkę konkurencyjną z przewoźnikami tradycyjnymi. Ci zaś zapożyczają pewne rozwiązania od tanich linii lotniczych i proponują pasażerom rozwiązania hybrydowe, korzystając z doświadczeń linii niskokosztowych. Należy mieć nadzieję, że ta konkurencja będzie wpływała pozytywnie na rynek przewozów w transporcie lotniczym, a największe korzyści będą odnosić podróżujący samolotami pasażerowie.

\section{Literatura}

Airbus, 2010, Airbus Global Market Forecast 2009-2030, Airbus, Tulouse, s. 13.

BA owner to launch low-cost flights to US from Barcelona, 23.12.2016, www.theguardian.com/business/2016/dec/23/ba-owner-to-launch-low-cost-flights-to-us-from-barcelona (15.02.2017).

Biskup K., 2013, Alianse strategiczne - rozwiąaniem problemu upadajacych przedsiębiorstw lotniczych, Studia z Zakresu Prawa, Administracji i Zarządzania, UKW, t. 4.

Can Norwegian really offer bargain transatlantic no-frills flights?, 2.07.2014, www.theguardian.com/ money/2014/jul/02/norwegian-bargain-flights-no-frills (15.02.2017).

Current Market Outlook 2011-2030, Boeing Commercial Airplanes, 2011, s. 5-32.

Koźlak A., 2007, Ekonomika transportu. Teoria i praktyka gospodarcza, Wydawnictwo UG, Gdańsk.

Malara Z., 2006, Przedsiębiorstwo w globalnej gospodarce. Wyzwania wspótczesności, PWN, Warszawa.

McWhirter A., 2014, Polecieć tanio za ocean. Czy to możliwe?, 7.02.2014, http://businesstraveller.pl/ rankingi/poleciec-tanio-ocean-mozliwe/2 (15.02.2017).

Monaghan A., 2016, Norwegian plans New York flights for under £60, 29.12.2016, www.theguardian. $\mathrm{com} /$ business/2016/dec/29/norwegian-plans-new-york-flights-under-60-pounds (14.02.2017).

Piotrowski M., 2017, Będa tanie loty z Europy do Azji! AirAsia X wraca po 5 latach $i$ zapowiada bardzo niskie ceny, 30.01.2017, http://www.fly4free.pl/beda-tanie-loty-z-europy-do-azji-airasia-x-wracapo-5-latach-i-zapowiada-bardzo-niskie-ceny/ (15.02.2017).

Rucińska D. (red.), 2015, Rynek uslug transportowych w Polsce, PWE, Warszawa.

Rucińska D., Ruciński A., Tłoczyński D., 2012, Transport lotniczy. Ekonomika i organizacja, Wydawnictwo UG, Gdańsk. 
Sipiński D., 2017, Ryanair dowiezie pasażerów Norwegianowi i Aer Lingus, 24.01.2017, http://www.pasazer.com/news/33168/ryanair,dowiezie,pasazerow,norwegianowi,i,aer,lingus.html (15.02.2017).

Tłoczyński D., 2013, Kierunki rozwoju transport lotniczego, Studia Ekonomiczne, Zeszyty Naukowe Wydziałowe Uniwersytetu Ekonomicznego w Katowicach, nr 143, s. 384.

Tłoczyński D., 2015, Raport lotniczy za rok 2015, Wiadomości Turystyczne, Warszawa.

Wojewódzka-Król K., Załoga E. (red.), 2016, Transport. Nowe wyzwania, PWN, Warszawa. 